\title{
Study of Nitrogen Pollution Simulation and Management Measures on SWAT Model in Typhoon Period of Shanxi Reservoir Watershed, Zhejiang Province, China
}

\author{
Haitao Chen" ${ }^{1}$, Jing Chen², Yuanyuan Liu', Ji He ${ }^{1, *}$ \\ 'School of Water Resources, North China University of Water Resources and Electric Power, China \\ ${ }^{2}$ Water Resources Development Planning and Design Co., Ltd, China
}

Received: 19 July 2020

Accepted: 3 November 2020

\begin{abstract}
In this study, the Shanxi Reservoir watershed, which is greatly affected by typhoons, is used as the research object, two daily scale SWAT models are established for the dry and wet seasons. Two different typhoon processes in 2007 and 2008 are selected to analyze the pollutant loads during the typhoon period and the reduction of the pollution loads by filter strips. This study focuses on the pollutant load during the typhoon and the reduction effect of management measures, proves seasonal modeling according to regional climate characteristics dramatically improves the accuracy of the model, broadens the perspective of watershed pollution prevention and control. The results show that: the pollutant output of the Shanxi Reservoir watershed is mainly agricultural land, and is positively correlated with precipitation and runoff; loads of organic nitrogen and nitrate nitrogen during typhoon 1 and typhoon 2 accounted for $22.18 \%$ and $9.14 \%, 22.53 \%$, and $18.08 \%$ of the whole year, respectively. The pollution loads of typhoon 2 relative to typhoon 1 is relatively small; when the width of the filter strips reaches $3 \mathrm{~m}$, the reduction of ammonia nitrogen loads can reach more than $50 \%$, which proves a visible effect on reducing pollutant loads during typhoons.
\end{abstract}

Keywords: SWAT model, water source, dry and wet seasons, typhoon, pollution load

\section{Introduction}

In recent years, the global climate has continued to warm, and issues such as rainstorms and droughts have received continuous attention [1-2]. Among the

*e-mail: huashui321@126.com

many extreme weather conditions, the frequency of typhoons shows an upward trend [3]. Scholars have conducted a lot of research from confluence and flood formation, soil erosion, and sediment transport [4-5]. Extreme rainfall events will have a significant impact on river water quality risks, especially in areas that are significantly affected by non-point source pollution (NPS). However, there are relatively few studies on this aspect. At the same time, due to the characteristics of 
NPS, such as strong randomness, wide distribution, long incubation period, and difficult to estimate [6]. It is difficult to control its pollution and has a high cost. For the research of NPS, empirical models, such as the LOADEST model [7] or mechanism models such as the SWAT model, HSPF, etc. [8], are mostly used.

Among the many models, the SWAT (Soil and Water Assessment Tool) model is an essential tool for hydrological simulation of large-scale complex watersheds. It has been widely used in hydrological cycles, soil erosion, pollutant loads, climate change, and the impact of landuse changes [9, 10]. Li et al. [11] simulated the SWAT model and the QUAL2E model with tight coupling and loose coupling. The results showed that the simulation results of $\mathrm{TN}$ and TP were not significantly different between the high water period and the average water period. Under mixed precipitation and runoff conditions, there was a significant difference in the amount of NPS into the river. It was not enough to just determine the pollutant changes throughout the year. NPS slope generationtransport process brought by extreme precipitation causes pollutants to carry pollution loads on land slopes along with the runoff and sediment transport [12]. Based on the SWAT model, Che et al. [13] found that the pollutant loads showed a significant increasing trend during heavy rains through the change process of the main pollutant flux during the extreme rainfall process in the Dongjiang River Basin and its impact on water quality. It has the characteristics of a short time and a strong effect of pollutant loads. However, the above research also has certain limitations. They did not take into account the variability of the model parameters within the year, making the model unable to simulate the actual situation in the study area.
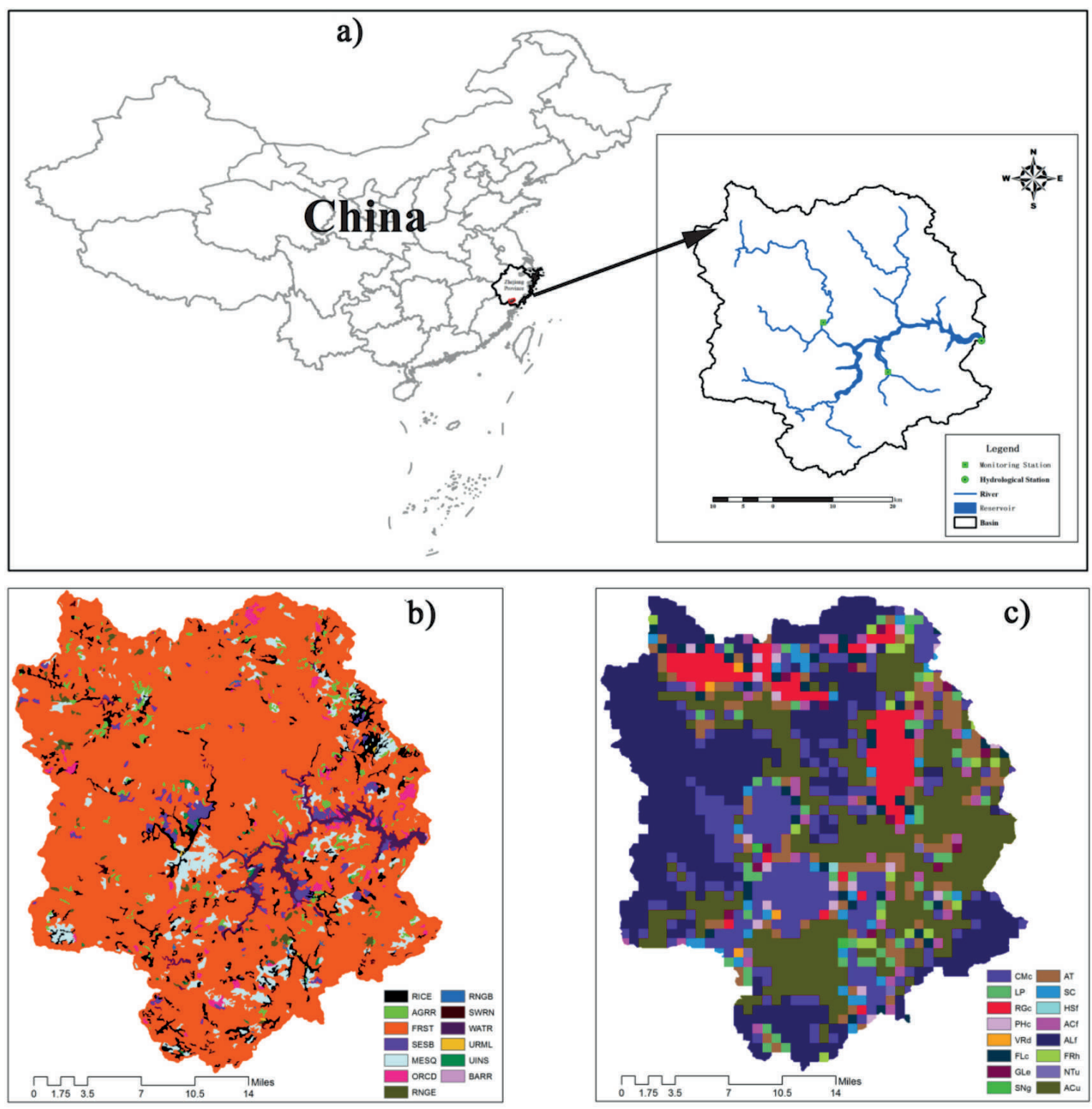

Fig. 1. Location of the study area. 
Shanxi Reservoir watershed is a vital water source in the southeast of Zhejiang Province, China, and has high requirements for water quality. Due to geographical location, it is often affected by extreme weather such as typhoons. The objectives of this study are to clarify the pollutant changes during typhoons and seek the best management measures for the protection of the water quality of the water source. In this study, with full consideration of the difference between the underlying surface during the flood season and the nonflood season within the year in the study area, two daily scale SWAT models are established for the dry and wet seasons to discuss the changes in the nitrogen pollution loads of the Shanxi Reservoir watershed during the typhoon. At the same time, the research on the interception of nitrogen pollution load by filter strips is studied to provide a basis for decision-making for water pollution control and treatment under the limited data and changing scenarios.

\section{Material and Methods}

\section{Study Area}

The study area of this paper is the Shanxi Reservoir watershed, which is located in the middle reaches of the Feiyun River in southeastern Zhejiang Province, China. The reservoir is a protection zone for water source (Fig. 1). Most of the rivers in the study area are mountainous rivers, which have a sizeable specific drop, steep bank slopes, and short confluence time. The area of the reservoir controlled watershed is 1529 $\mathrm{km}^{2}$, accounting for $47 \%$ of the total area of the Feiyun watershed. The multi-year average runoff of the basin is 1.8 billion $\mathrm{m}^{3}$, and the full storage capacity of the reservoir is 1.804 billion $\mathrm{m}^{3}$. The annual water supply of the reservoir is 1.34 billion $\mathrm{m}^{3}$. The water supply area is the Wenrui Plain and the area south of the Feiyun River. The water supply area benefits 5 million people. There are three counties of Taishun, Wencheng, and Jingning in the watershed, and the agricultural economy dominates the economic composition of each county. The landuses in the basin are mainly forest land, which accounts for about $71 \%$ of the total area, followed by agricultural land, which accounts for about $20 \%$. In forest land, the proportion of coniferous forest and the broad-leaved forest is $70 \%$ and $10 \%$, respectively [14].

The Shanxi Reservoir watershed is located in a low-latitude area, relatively close to the East China Sea, with sufficient precipitation, and belongs to the subtropical monsoon climate zone. In the late winter and early spring, due to the influence of the northward advance of the subtropical high, the precipitation was dominated by light rain. In late spring and early summer, due to the warm Pacific high pressure gradually advancing toward the mainland and moving in the basin, continuous precipitation was formed, commonly known as "plum rain." From July to September, due to the influence of the subtropical high, typhoon activity was frequent in the study area, which would cause significant floods. In the fall, the subtropical high moves eastward, and precipitation decreases. Winter weather is mainly sunny and cold, with little rain and snow.

\section{Data Source}

The data required by the research include the digital elevation model (DEM), soil, land use, hydrometeorology, and pollution data. Among them, the DEM data scale is 1: 50000, and the spatial resolution is $30 \mathrm{~m}$, which is derived from ASTER Version2 data. Land use data is based on Landsat TM $30 \mathrm{~m}$ remote sensing image, interpreted according to the national land use classification method, and divided into 6 first-level categories and 25 second-level categories. Then 13 kinds of land were reclassified, which can be identified by the SWAT model (Fig. 1b) [15]. Using the HWSD data downloaded from the Science Data Center of Cold and Arid Regions, with a spatial resolution of $1 \mathrm{~km}$, reclassified it to obtain a total of 16 soil types (Fig. 1c). Meteorological data are derived from daily observations from four stations in the study area and provided by the local meteorological department. The time series is from 1956 to 2012. The data includes precipitation, temperature, evaporation, etc. The location of the meteorological station in the basin is shown in Fig. 1a). The hydrological data is the daily runoff data from 2007 to 2012, which was monitored by the local Water Resources Bureau. The hydrological station is located at the outlet of the basin, and its location is shown in Fig. 1a). The pollutant data comes from the statistical yearbook of the city where the study area is located. TN in Shanxi Reservoir was monitored by the local Water Resources Bureau on an approximately monthly basis during 2009-2012.

\section{SWAT Model}

In this study, SWAT2012 is used as a research tool, and the collected data are used to establish the spatial database and attribute database required by the model. Apply the SUIF-2 calculation method of SWAT-CUP software to calibrate the model parameters, and analyze the uncertainty and sensitivity of the model parameters [16].

The SWAT water quality model is constructed under the principle of calibrating hydrological parameters first and then calibrating pollution load parameters. Firstly, we established a monthly runoff model of the Shanxi Reservoir watershed to make the parameters meet the model requirements. Generally, routine water quality monitoring in China does not include organic nitrogen and nitrate nitrogen. After the hydrological model calibration is completed, we use TN data to calibrate the water quality parameters. Due to the lack of observed data of organic nitrogen and nitrate nitrogen, we use the simulated output data of the established SWAT 
water quality model to study the pollution load. In the monthly scale model, the warm-up period is from 2004 to 2006 , the calibration period is from 2007 to 2010 , and the validation period is from 2011 to 2012 .

As for water source, Shanxi Reservoir has exceptionally high water quality requirements. Among the many management measures built into the SWAT model, the filtered zone is considered to be an effective measure to intercept sediment, nutrients, pesticides, and bacteria [17]. In this study, we sought the best pollutant interception solution by setting filter strips of different widths (1-10m). To evaluate the effect of filter strips on pollutant load reduction in the watershed, we use the following equation:

$$
\mathrm{R}=1-\frac{L_{A}}{L_{B}}
$$

...where, $\mathrm{R}$ is the pollutant load reduction rate, $L_{B}$ is the pollutant load at the outlet of the watershed before setting filter strips, and $L_{A}$ is the pollutant load at the outlet of the basin after placing filter strips.

\section{Selection of Typical Typhoons}

The Shanxi Reservoir watershed is a typical area affected by typhoons. Extreme meteorological factors such as heavy precipitation will exacerbate NPS and soil erosion. This research selected two typical typhoon processes to study their impact on water quality. At the same time, the effect of filter strips on reducing nitrogen pollution load during typhoon was studied. The first typhoon process we chose occurred from August 13 to August 20, 2007. The name of the typhoon is Sepat, and the typhoon number is 200709, which is called typhoon 1 . The reason why the typhoon was selected was that the precipitation for two consecutive days reached $347 \mathrm{~mm}$ on August 18-19, 2007, which was the most massive two-day precipitation from 2007 to 2012. The two days of precipitation accounted for the annual rainfall of $14 \%$ of the amount. At the same time, on August 19, 2007, the runoff reached $2391 \mathrm{~m}^{3} / \mathrm{s}$.

The second typhoon process we chose occurred from July 15 to July 30, 2008. It included two consecutive typhoon processes, namely Typhoon Seagull, No. 200807, and Typhoon Phoenix, No. 200808. This typhoon process is called typhoon 2 . The reason why this typhoon was selected is that the typhoon process lasted for 16 days of continuous precipitation.

\section{Results and Discussion}

\section{Simulation Results of Runoff and Pollutants}

This study uses the three statistical parameters ENS, $\mathrm{R}^{2}$, and PBIAS, to evaluate the applicability of the model. Generally, $E N S \geq 0.75$ indicates that the model calibration is excellent, and $0.36 \leq E N S \leq 0.75$ suggests that the model calibration results are acceptable. For $\mathrm{R}^{2}$, the closer to 1 , showing that the model is more accurate. For PBIAS, the result is within $10 \%$, meaning that the model calibration result is outstanding, which is acceptable in the range of $15 \% \leq \mathrm{PBIAS} \leq 25 \%$. For the pollution load, the result within $40 \% \leq \mathrm{PBIAS} \leq 70 \%$ could be acceptable [18]. First, we establish a monthly runoff and water quality model of the Shanxi Reservoir watershed. When the calibration results of runoff and water quality meet the accuracy requirements of the model, we used the calibrated water quality parameters and daily runoff data to establish the daily scale model. Since the study area is located in a region with extremely uneven distribution during the precipitation year, when constructing the daily scale model, we consider dividing the whole year into dry season and wet season, and carry out the model establishment and parameter calibration respectively. According to the precipitation characteristics of the study area, we define the wet season from April 1 to September 30 each year, and the dry season from October 1 to March 31 of the following year. First, calibrate the runoff parameters of the two daily scale models in the dry and wet seasons. When the calibration results meet the applicability requirements of the model, substitute the calibrated pollution load parameters of the monthly scale hydrological and water quality models to establish the Shanxi Reservoir watershed daily Scale SWAT model of nitrogen pollution.

The applicability parameter results of the SWAT model are shown in Table 1 , and the simulated and observed values of monthly runoff and $\mathrm{TN}$ load are shown in Fig. 2. It can be seen from Table 1 that the ENS and $\mathrm{R}^{2}$ of the model runoff calibration and validation period on the monthly scale are above 0.84 , and the PBIAS is within $2 \%$. It can be seen from Fig. 2a) that the trends of the simulated and observed values of monthly runoff are in good agreement, and the fitting of peak and valley values is ideal. For TN load, both ENS and $\mathrm{R}^{2}$ during calibration and verification are higher than 0.7 , and PBIAS is within $40 \%$. For the NPS model, the simulation results are relatively good. It can be seen from Fig. 2b) that the simulated and observed trends of TN load are the same, the peak fitting is slightly biased, and the fitting effect in other periods is good.

The calibration of the daily scale model runoff and the fitting of the observed values are shown in Fig. 3, and the relevant parameter results are shown in Table 1. It can be seen from Fig. 3 that both the dryseason and wet-season daily-scale models have realized the simulation of runoff and are consistent with the simulation trends. The fit of extreme values is also high. It can be seen from Table 1 that the effect of the dry season model is better than that of the wet season, especially the validation period of the dry season, where both ENS and $\mathrm{R}^{2}$ are above 0.9 . This may be due to the frequent occurrence of typhoons during the 


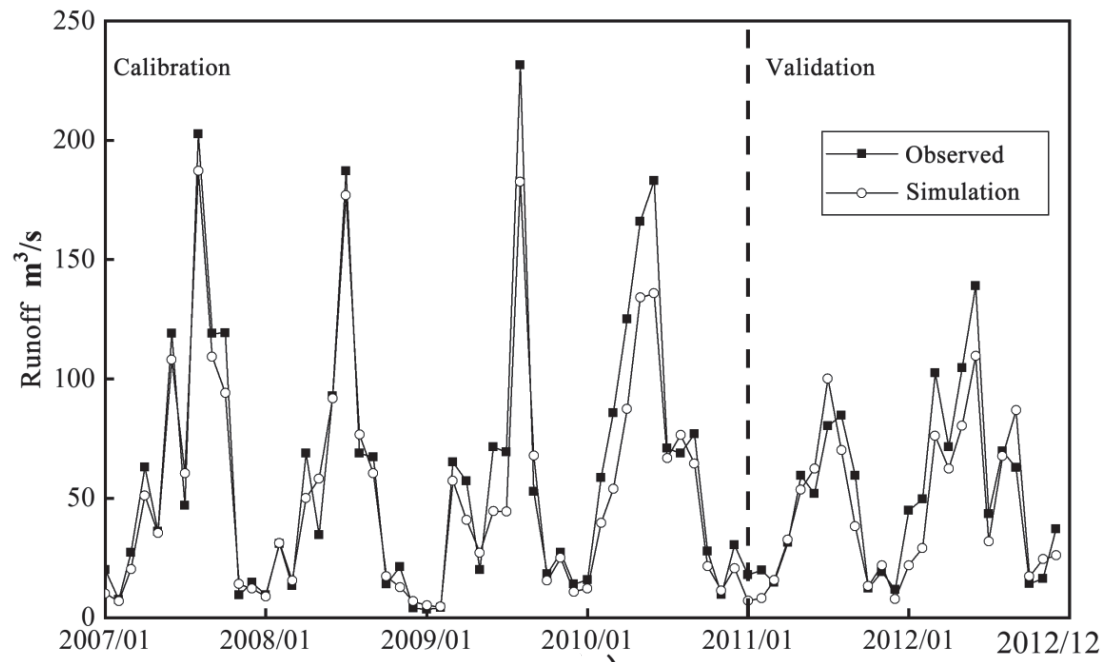

a)

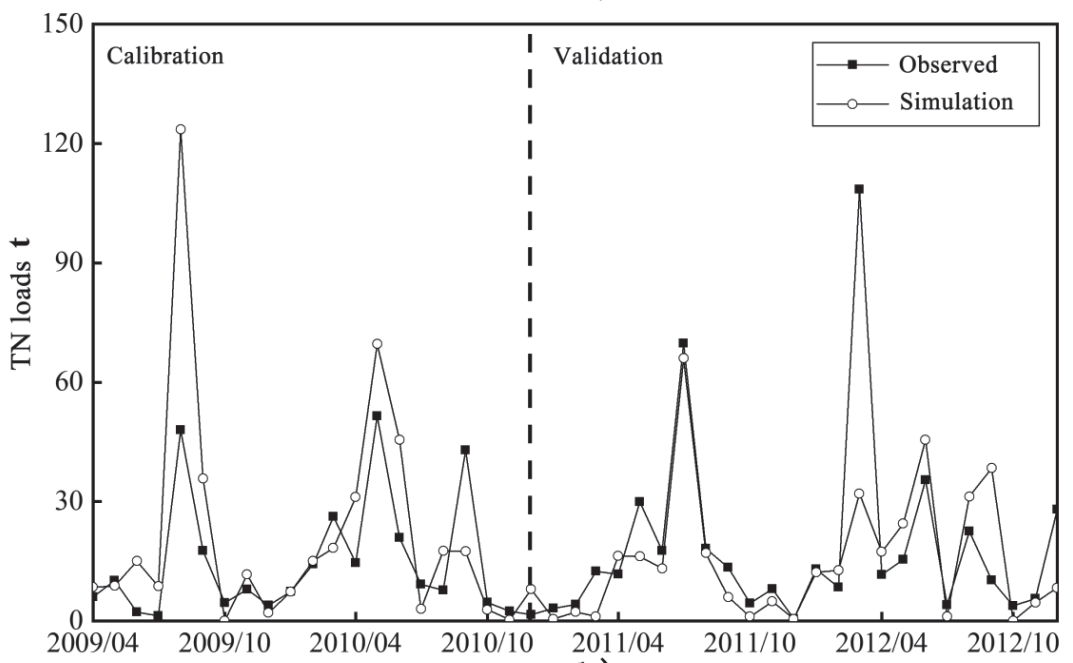

b)

Fig. 2 Comparison between the observed value and simulated value of monthly runoff and TN load.

wet season in the Shanxi Reservoir Basin, resulting in a significant annual change in precipitation, which increases the uncertainty of the model parameters. The research on the SWAT model by Lin et al. also proved that the more stable weather conditions in the dry season improved the accuracy of the simulation [19]. During the calibration and validation period of the wet season model, both ENS and $\mathrm{R}^{2}$ are higher than 0.67. The PBIAS for the calibration and validation periods of both models is within $10 \%$.
The Impact of Different Typhoon Periods on the Pollution Load at the HRUs

The HRUs (Hydrological Response Units) output of the SWAT model includes the nitrate nitrogen and organic nitrogen output of each HRU in the watershed. Because the HRU output file does not contain ammonia nitrogen, this study uses only nitrate nitrogen and organic nitrogen to assess the impact of typhoons on nitrogen pollution load. The nitrogen pollutant loads of

Table 1. Calibration and validation results of runoff and TN load.

\begin{tabular}{|c|c|c|c|c|c|c|c|}
\hline \multirow{2}{*}{ Time Scale } & \multirow{2}{*}{ Simulation } & \multicolumn{3}{|c|}{ Calibration } & \multicolumn{3}{c|}{ Validation } \\
\cline { 3 - 9 } & & ENS & $\mathrm{R}^{2}$ & PBIAS(\%) & ENS & $\mathrm{R}^{2}$ & PBIAS(\%) \\
\hline \multirow{3}{*}{ Monthly } & Runoff & 0.94 & 0.95 & -0.07 & 0.84 & 0.85 & 1.85 \\
\cline { 2 - 9 } & $\mathrm{TN}$ & 0.70 & 0.73 & -13.0 & 0.75 & 0.86 & -31.3 \\
\hline \multirow{2}{*}{ Daily } & Runoff (dry) & 0.76 & 0.74 & 9.3 & 0.91 & 0.92 & -6.8 \\
\cline { 2 - 9 } & Runoff (wet) & 0.73 & 0.73 & 4.4 & 0.67 & 0.68 & -7.0 \\
\hline
\end{tabular}




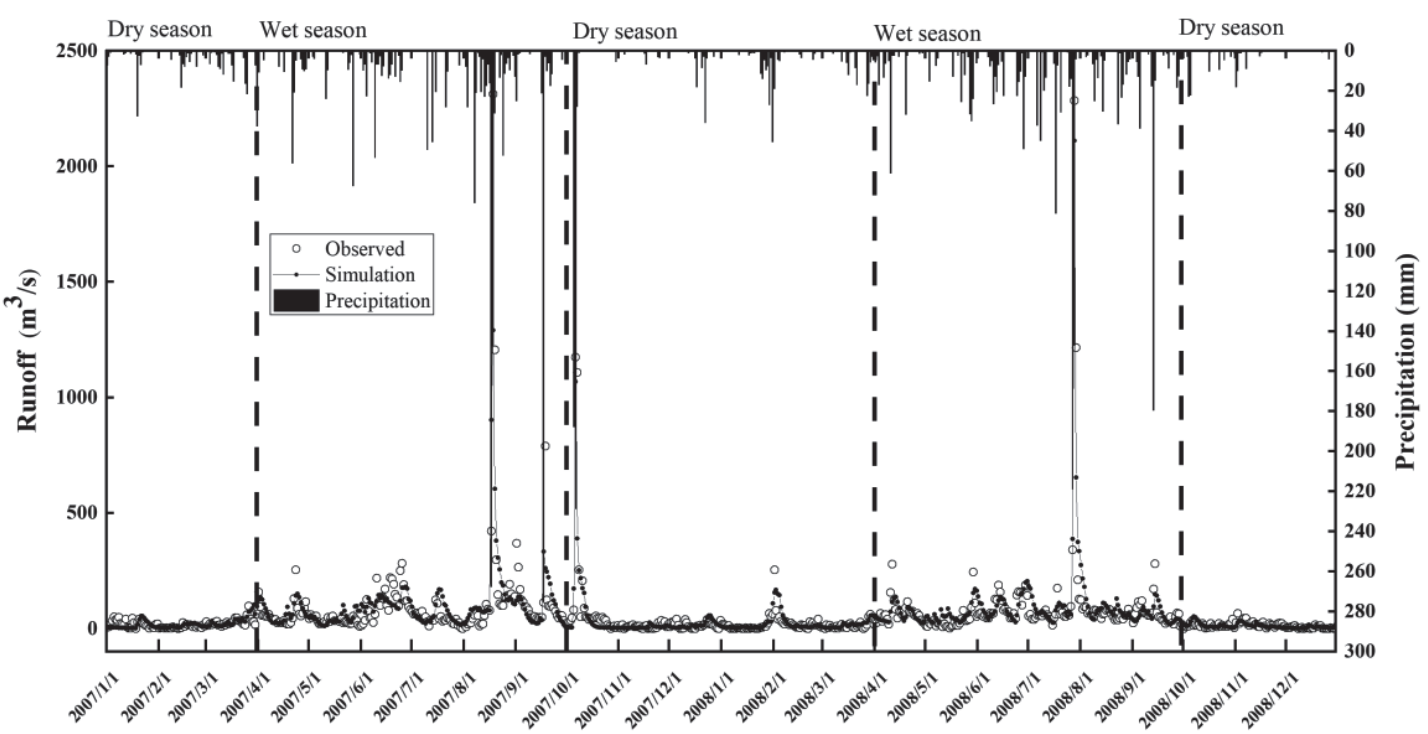

a)

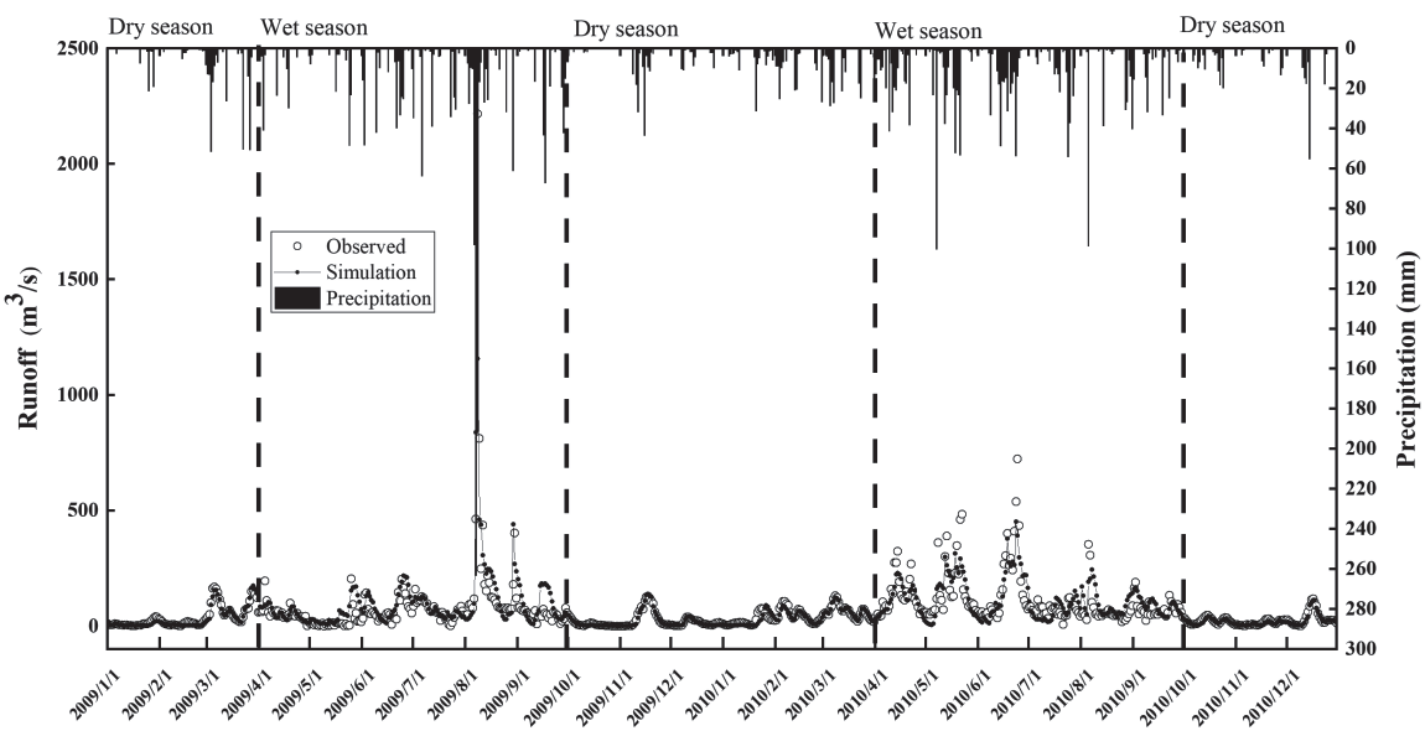

b)

Fig. 3. Comparison between the observed value and simulated value of daily runoff: a) Calibration period of dry and wet seasons from 2007 to 2008; b) Validation period of dry and wet seasons from 2009 to 2010.

different landuses in the Shanxi River Basin in 2007 and 2008 is shown in Table 2. It can be seen that the pollutant load of agricultural land (including paddy fields and dry fields) in the past two years is the largest among all landuses, which is dozens of times that of forest land and grassland.

The analysis of the nitrogen pollution loads of different landuses in the study area in 2007 and 2008 show that the pollution loads is mainly organic nitrogen and nitrate nitrogen, which is directly related to the backward agricultural cultivation methods in the basin. Abuse of manure and inorganic fertilizer and unscientific fertilization methods are essential causes of nitrogen pollution [20]. In most agrarian farming areas in China, fertilizers are directly applied to the surface of the land, which causes a large amount of fertilizer to be lost into the river along with surface runoff without being effectively used [21]. By consulting the statistical yearbook, we can find that there is also the abuse of chemical fertilizers in the study area [22]. For non-agricultural areas, their soil and water conservation capabilities are better, less affected by human activities, and have fewer sources of pollutants, so the pollution loads is smaller [23]. The pollutant loads of various landuses in the Shanxi Reservoir watershed also exhibit the above characteristics.

The output of HRUs is used to analyze the change of pollutants during two typhoons quantitatively. The simulation results show that the pollutant load during the typhoon is huge (Table 3). The daily load per unit area 
Table 2. Pollution load of different landuses in 2007 and 2008.

\begin{tabular}{|c|c|c|}
\hline Landuses & $\begin{array}{c}\text { Organic nitrogen } \\
\mathrm{t} / \mathrm{km}^{2} / \text { day }\end{array}$ & $\begin{array}{c}\text { Nitrate nitrogen } \\
\mathrm{t} / \mathrm{km}^{2} / \text { day }\end{array}$ \\
\hline \multicolumn{3}{|c|}{2007} \\
\hline Agricultural land & 3.18 & 17.98 \\
\hline Grassland & 0.82 & 0.04 \\
\hline Forest & 0.13 & 0.92 \\
\hline Orchard & 1.88 & 8.95 \\
\hline 2007 average & 0.34 & 1.24 \\
\hline \multicolumn{2}{|c|}{2008} & 9.62 \\
\hline Agricultural land & 3.17 & 0.01 \\
\hline Grassland & 1.13 & 0.49 \\
\hline Forest & 0.08 & 3.44 \\
\hline Orchard & 1.38 & 0.60 \\
\hline 2008 average & 0.27 & \\
\hline
\end{tabular}

of organic nitrogen and nitrate nitrogen during typhoon 1 was $3.44 \mathrm{t} / \mathrm{km}^{2} /$ day and $5.17 \mathrm{t} / \mathrm{km}^{2} /$ day, respectively. During typhoon 2, loads of organic nitrogen and nitrate nitrogen were $1.11 \mathrm{t} / \mathrm{km}^{2} /$ day and $1.98 \mathrm{t} / \mathrm{km}^{2} /$ day. A load of organic nitrogen and nitrate nitrogen during typhoon 1 accounted for $22.18 \%$ and $9.14 \%$ of the whole year, respectively. For typhoon 2, organic nitrogen and nitrate nitrogen load accounted for $22.53 \%$ and $18.08 \%$ of the year, respectively. Although organic nitrogen accounts for the same proportion of the whole year, it should be noted that the duration of typhoon 1 is only half of the number of typhoons.

Table 3. Pollution load of different landuses during typhoon 1 and typhoon 2 .

\begin{tabular}{|c|c|c|}
\hline Landuses & $\begin{array}{c}\text { Organic nitrogen } \\
\text { t/ } \mathrm{km}^{2} / \text { day }\end{array}$ & $\begin{array}{l}\text { Nitrate nitrogen } \\
\mathrm{t} / \mathrm{km}^{2} / \text { day }\end{array}$ \\
\hline \multicolumn{3}{|c|}{ Typhoon 1} \\
\hline Agricultural land & 41.21 & 64.45 \\
\hline Grassland & 14.13 & 0.05 \\
\hline Forest & 1.12 & 2.7 \\
\hline Orchard & 20.42 & 20.64 \\
\hline $\begin{array}{l}\text { Average during } \\
\text { typhoon } 1\end{array}$ & 3.44 & 5.17 \\
\hline \multicolumn{3}{|c|}{ Typhoon 2} \\
\hline Agricultural land & 11.13 & 25.17 \\
\hline Grassland & 2.46 & 0.05 \\
\hline Forest & 0.57 & 1.01 \\
\hline Orchard & 6.02 & 6.27 \\
\hline $\begin{array}{l}\text { Average during } \\
\text { typhoon } 2\end{array}$ & 1.11 & 1.98 \\
\hline
\end{tabular}

The comparison of the pollution loads during the two typhoons found that there is some consistency between them. For example, agricultural land is the primary source of nitrogen pollution load, and the unit load is more than ten times the average. For the two typhoon periods, the load of the forest land during the typhoon period accounted for the smallest annual average load. Due to the massive runoff generated by typhoon 1, and the long typhoon period of typhoon 2, the characteristics of the two typhoons are different, showing different correlations between rainfall and runoff and pollution loss.

The analysis of the nitrogen pollutant load during the two typhoons indicates that the heavy precipitation and extreme runoff brought by the typhoon are the main causes of water pollution in the Shanxi Reservoir watershed. The result is consistent with other studies on NPS caused by soil erosion [24-25]. Therefore, the focus of the water environment management work of the Shanxi Reservoir watershed should be implemented in the prevention and control of water pollution during extreme weather.
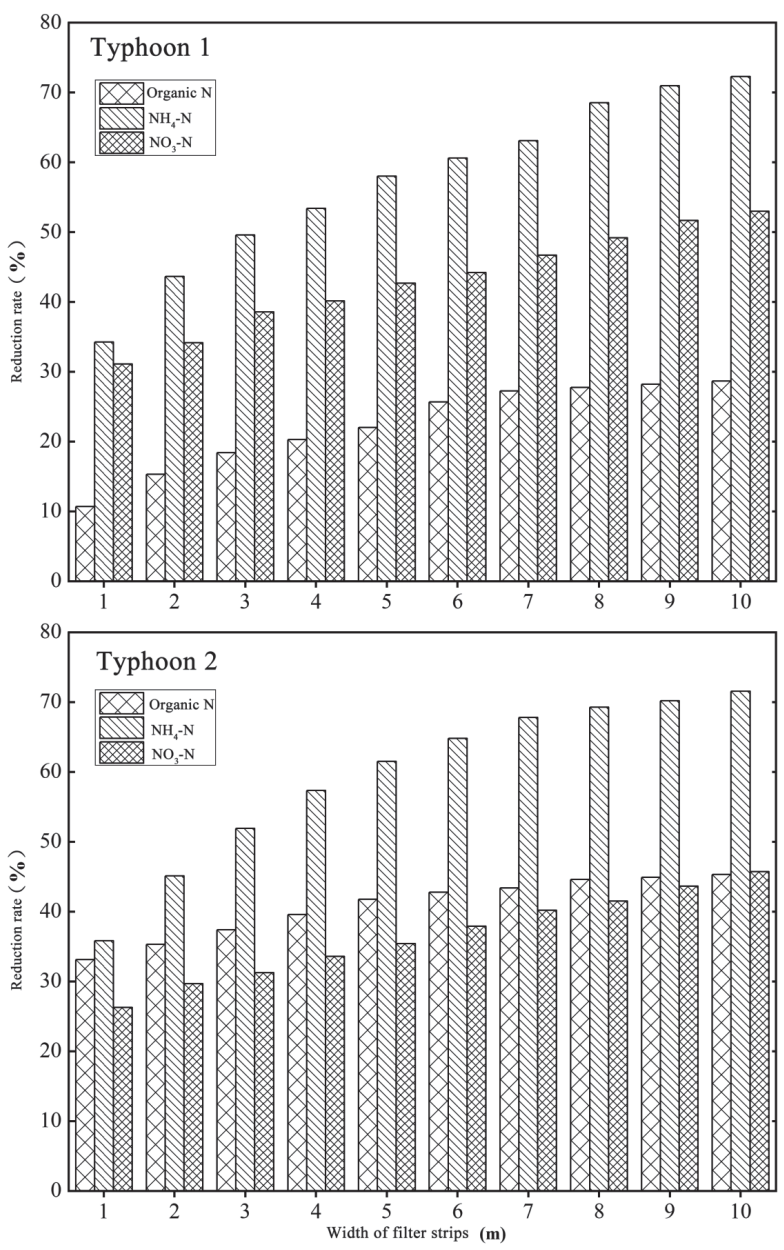

Fig. 4. Effects of filter strips with different widths on pollutants. 


\section{Impact of Filter Strips on Pollution Reduction}

In this study, the filter stripe is selected as the management measure. In the SWAT model, different land use can be chosen as the areas for setting filter strips, such as habitat, grasslands, and agricultural land. In addition, the time when the filter strips take effect, and the width of it can be set, which makes the scenario settings more flexible [17]. In this study, we selected the areas most affected by NPS, set up filter strips on the HRUs where agricultural land is located. The time when filter strips take effect is set to be from July 1 to September 30 every year. This period is the foremost time affected by the typhoon in the Shanxi Reservoir basin and part of the wet season time series.

It can be seen from Fig. 4. That filter stripe has an excellent effect on reducing nitrogen pollution. The filter strips show the best result of reducing ammonia nitrogen load during both typhoon periods. The impact of lowering organic nitrogen and nitrate nitrogen is different during the two typhoons. When the width of the filter stripe is $3 \mathrm{~m}$, the reduction of ammonia nitrogen load can reach more than $50 \%$. When the width of the filter strips reaches $10 \mathrm{~m}$, the effect of reducing the pollution load is the best. The buffer zone composed of different plants can effectively intercept pollutants into the water, and this point has been proved in some annual and monthly model studies [26-27]. This research shows that during typhoons, due to extreme precipitation and runoff, a sudden increase in pollution load requires a wider filter strip [28].

However, filter strips only intercept pollution load from the perspective of engineering measures, and cannot reduce the source of pollution. A comparison of the output of pollutants from different landuses found that agricultural land is the most critical output type during typhoon periods or other periods. Therefore, changing the nature of farmland and farming methods is an effective way to protect water sources and improve water quality. Many studies have also shown that reducing the application of fertilizers and improving the processes of fertilization are effective means to reduce the pollution load on agricultural land [29]. The determination of management measures should not only consider the reduction of pollution loads but also consider the impact on ecology and socio-economic [30]. Changing the type of agricultural land, reducing the amount of fertilizer application, and to a certain extent leading to a reduction in food production will inevitably reduce the income of local farmers, which will bring a series of social problems and even affect national food safety [31]. In the short term, the filter strips have a small impact on the social economy and is a relatively feasible measure. Still, in the long run, source control should be implemented to reduce the pollutant load in the watershed [32].

\section{Conclusions}

1) Whether it is runoff simulation or pollutant simulation, the applicability parameter results of the monthly scale model are excellent. The method of modeling dry season and wet season separately respond well to the characteristics of the frequent occurrence of extreme weather in the Shanxi Reservoir Watershed, and improves the accuracy of the model simulation

2) In 2007 and 2008, the primary land use type of pollution load was agricultural land, and the load was several tens of times that of other landuses. The main types of pollutants are organic nitrogen and nitrate nitrogen, which are mainly related to the abuse of manure and inorganic fertilizers in the study area and the unscientific addition methods.

3) The load of organic nitrogen and nitrate nitrogen during typhoon 1 accounted for $22.18 \%$ and $9.14 \%$ of the whole year, respectively. For typhoon 2, organic nitrogen and nitrate nitrogen load accounted for $22.53 \%$ and $18.08 \%$ of the year, respectively. The effect of the typhoon on organic nitrogen output is more prominent, which is directly related to the soil erosion caused by the typhoon. The focus of the watershed management agency should be on pollution prevention during typhoons.

4) Filter strips can intercept nitrogen pollution. When the width of the filter strips is $3 \mathrm{~m}$, the reduction of ammonia nitrogen load can reach more than $50 \%$. When the width of the filter strips reaches $10 \mathrm{~m}$, the effect of reducing the pollution load is the best. In the short term, this measure can be used for pollution prevention and control in the watershed, but in the long run, the source of pollution should be intercepted from the source.

\section{Acknowledgements}

The authors express their gratitude for the support provided by the Wenzhou Water Resources Bureau.

\section{Conflict of Interest}

The authors declare no conflict of interest.

\section{References}

1. ZHAI P., ZHOU B., CHEN Y. A Review of Climate Change Attribution Studies. Journal of meteorological research. 32 (5), 671, 2018 [In Chinese].

2. PAVEL Y.A., ROISMAN G., KNIGHT R.W., EASTERLING D.R., KARL T.R., HEGERL G.C., RAZUVAEV V.N. Trends in intense precipitation in the climate record. Journal of Climate. 18 (9), 1326, 2005.

3. REN F., WU G., DONG W., WANG X., WANG Y., AI W., LI W. Changes in Tropical Cyclone Precipitation Over China. Geophysical Research Letters. 33 (20), 25, 2006. 
4. LEE S.Y., HAMLET, A.F., GROSSMAN E.E. Impacts of Climate Change on Regulated Streamflow, Hydrologic Extremes, Hydropower Production, and Sediment Discharge in the Skagit River Basin. Northwest Science. 90 (1), 23, 2016.

5. XIE Z., YIN D.U., ZENG Y., MIAO Q. Classification of yearly extreme precipitation events and associated flood risk in the Yangtze-Huaihe River Valley. Science Chinaearth Sciences. 61 (9), 1341, 2018 [In Chinese].

6. WANG Y., YANG J., LIANG J., QIANG Y., FANG S., GAO M., FAN X., YANG G., ZHANG B., FENG Y. Analysis of the environmental behavior of farmers for nonpoint source pollution control and management in a water source protection area in China. Science of The Total Environment. 633, 1126, 2018.

7. JHA B., JHA M.K. Rating Curve Estimation of Surface Water Quality Data Using LOADEST. Journal of Environmental Protection. 4 (8), 849, 2013.

8. MINE A., ÖĞüTVEREN Ü.B., ALBEK E. Hydrological modeling of Seydi Suyu watershed (Turkey) with HSPF. Journal of Hydrology. 285 (1-4), 0-271, 2004.

9. SURHONE L.M., TENNOE M.T., HENSSONOW S.F. Soil and Water Assessment Tool. 2010.

10. TAN M.L., GASSMAN P., YANG X., HAYWOOD J. A review of swat applications, performance and future needs for simulation of hydro-climatic extremes. Advances in Water Resources. 143, 103662, 2020.

11. LI D., XUE L., HAO Z. SWAT simulation of effect of stream water quality on non-point source pollution. Environmental Pollution \& Control. 30 (3), 4, 2008 [In Chinese].

12. CHENG H., HAO F., REN X., YANG S., XIONG W. The study of the rate loss of nitrogenous non-point source pollution loads in different precipitation levels. Acta Scientiae Circumstantiae. 26 (3), 392, 2006 [In Chinese].

13. CHE R., LIN S., FAN Z., LI W., ZENG F., MAO B., HUANG, Z. Effects of Continuous Extreme Rainfall on Water Quality of the Dongjiang River Basin. Environmental Science. 40 (10), 4440, 2019 [In Chinese].

14. MEI K., SHANG X., WANG Z., HUANG S., DONG $X$., HUANG H. Influence of land use on memory effect of watershed nitrogen. Acta Scientiae Circumstantiae. 36 (10), 3856, 2016 [In Chinese].

15. NING J., LIU J., KUANG W., XU X., ZHANG S., YAN C., LI R., WU S., HU Y., DU G. Spatiotemporal patterns and characteristics of land-use change in China during 2010-2015. Journal of Geographical Sciences. 28 (5), 547, 2018.

16. KHALID K., ALI M.F., RAHMAN N.F.A., OTHMAN Z., BACHOK M.F. Calibration Assessment of the Distributed Hydrologic Model Using SWAT-CUP. 2018.

17. SHAN N., RUAN X.-H., XU J., PAN Z.-R. Estimating the optimal width of buffer strip for nonpoint source pollution control in the Three Gorges Reservoir Area, China. Ecological Modelling. 276, 51, 2014.

18. BROUZIYNE Y., ABOUABDILLAH A., BOUABID R., BENAABIDATE L. SWAT manual calibration and parameters sensitivity analysis in a semi-arid watershed in North-western Morocco. Arabian Journal of Geosciences. 10 (19), 427, 2017.
19. LIN B., CHEN X., YAO H., ZHANG D. Improved calibration scheme of SWAT by separating wet and dry seasons. Ecological Modelling. 2015.

20. XIANG P.A., YAN Z., HUANG H., HUA Z. Discussion on the Green Tax Stimulation Measure of Nitrogen Fertilizer Non-Point Source Pollution Control - Taking the Dongting Lake Area in China as a Case. Agricultural Sciences in China. 6 (6), 732, 2007 [In Chinese]

21. XIONGHUI J., SHENGXIAN Z., YANHONG L., YULIN L. Study of Dynamics of Floodwater Nitrogen and Regulation of Its Runoff Loss in Paddy Field-Based TwoCropping Rice with Urea and Controlled Release Nitrogen Fertilizer Application. Agricultural Sciences in China. 6 (2), 189, 2007 [In Chinese].

22. AIRU X., LINA M. On the Necessity and Prospects of Developing Organic Ecological Agriculture in Feiyun Lake. 36, 853+870, 2007 [In Chinese].

23. MEADOR M.R., GOLDSTEIN R.M. Assessing Water Quality at Large Geographic Scales: Relations Among Land Use, Water Physicochemistry, Riparian Condition, and Fish Community Structure. Environmental Management. 31 (4), 504, 2003.

24. JIN J.L., WANG F.E., DAI L.Y., TIAN P., ZHANG Z.J. Characteristics of non-point source pollution in Tiaoxi watershed and related affecting factors. Journal of Applied Ecology. 22 (8), 2119, 2011.

25. JIA H., LEI A., LEI J., YE M., ZHAO J. Effects of hydrological processes on nitrogen loss in purple soil. Agricultural Water Management. 89 (1), 89, 2007.

26. JANG S.S., AHN S.R., KIM S. Evaluation of executable best management practices in Haean highland agricultural catchment of South Korea using SWAT. Agricultural Water Management. 180, 224, 2017.

27. BLANCOCANQUI H., GANTZER C.J., ANDERSON S.H., ALBERTS E.E., THOMPSON A.L. Grass Barrier and Vegetative Filter Strip Effectiveness in Reducing Runoff, Sediment, Nitrogen, and Phosphorus Loss. Soil Science Society of America Journal. 68 (5), 1670, 2004.

28. DELETIC A., FLETCHER T.D. Performance of grass filters used for stormwater treatment - a field and modelling study. Journal of Hydrology. 317 (3), 261, 2006.

29. QIAO J., YANG L., YAN T., XUE F., ZHAO D. Nitrogen fertilizer reduction in rice production for two consecutive years in the Taihu Lake area. Agriculture, Ecosystems Environmental Processes. 146 (1), 103, 2012.

30. TANG Q., REN T., WILKO S., LIU H., LEI B., LIN T., ZHANG G. Study on Environmental Risk and Economic Benefits of Rotation Systems in Farmland of Erhai Lake Basin. Journal of Integrative Agriculture. 11 (6), 1038, 2012.

31. ZHANG X., GUO Q., SHEN X., SHENGWEN Y.U., QIU G. Water quality, agriculture and food safety in China: Current situation, trends, interdependencies, and management. Journal of Integrative Agriculture. 14 (11), $2365,2015$.

32. LIU L., HU Z.-Y. Selection of optimal agricultural nonpoint source pollution prevention and control techniques based on effect and cost of their pollution reduction: A case study of the taihu region. Journal of Ecology and Rural Environment. 31 (4), 608, 2015 [In Chinese]. 